\title{
Development of sustainable solutions to sand encroachment on roads in Kuwait using numerical modeling
}

\author{
Waleed Abdullah*, Ahmad Alzaza**, Rafaat Misak*** and Mohammed Amjad* \\ *Civil Engineering Department, Kuwait University, Kuwait \\ **Fiber and Particle Engineering, Faculty of Technology, University of Oulu, Finland \\ ***Kuwait Institute for Scientific Research, Kuwait \\ *Corresponding Author: waleed.abdullah@ku.edu.kw
}

Submitted: $12 / 12 / 2019$

Revised: $\quad 27 / 09 / 2020$

Accepted: $01 / 11 / 2020$

\begin{abstract}
Site reconnaissance of the threat of sand encroachment in Kuwait outlined major roads that were closed or partially closed for long periods of the year. These roads are AlSubia, AlWafra-Mena Abdallah, and AlWafra-AlZoor. Site surveys of the affected roads were undertaken to investigate the types and thicknesses of accumulated sand layers that were exposed to wind erosion. Soil samples were also collected to assess the particle size distribution. Wind data over the past 35 years were analyzed, which indicated that the prevailing direction is northwest with an average speed of 6-8 m/s. A preliminary concept design based on a composite system of natural and artificial elements was developed to be a sustainable protective system, which included double porous fences and green belts as major elements. Testing of the concept design model was performed in a virtual wind tunnel with different fence porosities and afforestation systems with the aid of the Autodesk Flow numerical model. Virtual wind tunnel results revealed that adopting 50\% porosity led to the optimum wind reduction $(\approx 75 \%)$, no turbulence area, and maximum sheltered area with no sand accumulation over the fences. The final design adopted was a composite made of artificial fences, green-belt trees, and gravel-stabilized areas, accompanied by removing the street barriers, achieving the aerodynamics concept to provide a long-term sustainable solution for the sand encroachment in those areas.
\end{abstract}

Keywords: Sand Encroachment; Sustainable; Optimum Porosity; Wind Tunnel.

\section{INTRODUCTION}

Sand encroachment occurs when sand grains are carried by the wind and are deposited on roads (Berte et al., 2010). The problem is particularly acute in desert regions where the ground surface is covered by dry loose sands, precipitation is rare, and vegetation is almost absent. Dong et al. (2002) and Katyal and Vlek (2000) reported that, during the last fifty years, several irrational development activities, such as overgrazing, divestment of vegetation cover, and other disturbances to the fragile arid ecosystem, have been responsible for increasing the risk of sand encroachment.

Many places in the world are affected by the phenomenon of sand encroachment. In Mauritania, Berte et al. (2010) reported that mobile sand dunes today cover two-thirds of the country's land area. Ayala and Goudie (2010) reported that roads in the desert of Chaidamu Basin, Western China, were endangered by sand encroachment. Similar cases 
were also reported in Algeria Sahara (Boulghobra et al., 2015) and Al Hasa, Saudi Arabia (Hidore and Abolkhair, 1982). In recent years, several defensive systems against sand encroachment have been tested to repel its negative impacts on economic growth and urban development (Cooke et al., 1982; Pye and Tsoar, 1990). The tested systems include removing and transporting the accumulated sand, trenching, planting, paving, paneling, fencing, and oiling (Kerr and Nigra, 1952; Cooke et al., 1982). Bert et al. (2010) reported that different solutions have been tested and applied all over the world to prevent transportation and drifting of sand either by modifying the wind/ground interface or increasing the surface roughness, such as the following:

- Spraying soil stabilizers, such as bitumen and lubrication oil. However, Dong et al. (2002) reported that chemical and clay fixers used to consolidate the side slopes of the road may not be extended on a large scale due to their prohibitive cost.

- Using mulch with synthetic staples or plant material such as culms and brushwood.

- Promoting the growth of microorganisms that may form rigid crusts that increase the resistance of sand to movement by the wind.

- Increasing the amount of vegetation.

The Taklimakan Desert highway $(447 \mathrm{~km})$ in China, which passes through the largest dune field in China and is the second largest shifting dune field in the world, is facing serious sand drift encroachment problems due to its passage through the area that consists of crescent dunes, barchan chains, compound transverse dune ridges, and complex mega-dunes (Dong et al., 2002; Zhiwen et al., 2003). To prevent the highway from being buried by sand, Chinese authorities have built a $60 \mathrm{~m}$ wide tree belt along the route provided with a massive irrigation system. Berte et al. (2010) reported that, in Mauritania, the aerodynamics method has been successfully applied to certain sections of the Road of Hope, although these sections must be monitored continuously.

In Kuwait, AlHelal and AlAwadhi (2006) reported that sand encroachment had become a serious economic and social problem. This problem is amplified, especially in areas where the accumulation of large amounts of sand on desert roads has caused their closures, either temporarily for cleaning or even permanently. Figure 1(a) shows a permanent closure of AlSubia Road, Figure 1(b) shows partially closed lanes of AlWafra-Mena Abdallah Road, and Figure 1(c) shows sand encroaching over AlWafra-AlZoor Road.

Because of the consequences of sand encroachment on the motorist's life and the economy of Kuwait, the government tends to apply several temporary measures, such as periodically removing the accumulated sand. The removed sands are dumped in the nearby open desert areas. Fine fractions of the dumped sands are redistributed by the wind to encroach other areas. Unfortunately, these measures consume effort, time, and cost without providing sustainable solutions. Moreover, the process of transportation of the removed sands to the surrounding areas causes severe disruption to soils, vegetation, and wildlife. Al-Awadhi and Misak (2000) reported that severe sand movement at the periphery of the agricultural areas in the southern part of the country has resulted in the complete failure of farms due to the adoption of mechanical (fences) and biological (trees) sand-control systems, which lacked a scientific basis. In some cases, such as the case of AlWafra-Mena Abdallah Road, two-meter-high bund walls (sand ridges) were established, 10-30 $\mathrm{m}$ on the upwind side of the roads. Saltating, loose sands gradually accumulated along these bund walls, and at a later stage, they encroached on the road. Al Hemoud et al. (2019) stated that sand, and to a lesser extent dust, is damaging and costly to the oil and gas infrastructure of Kuwait, with an economic cost estimation of US\$9.36 million, a total of 5159 nonproductive lost hours, and $347,310 \mathrm{~m}^{3}$ of annual sand removal. 


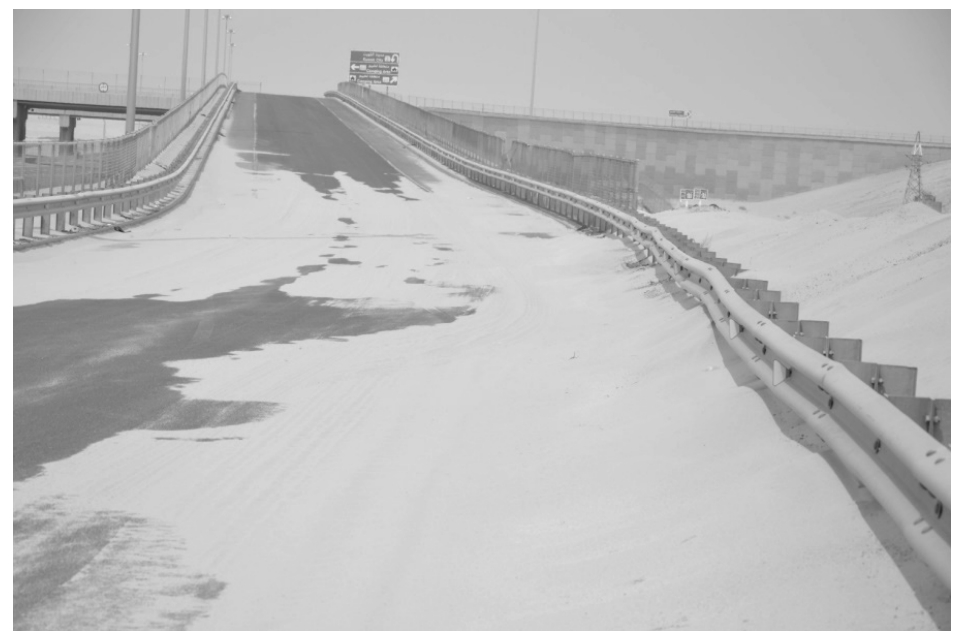

Figure 1(a). Permanent closure of AlSubia Road (Author's camera, June 2015).

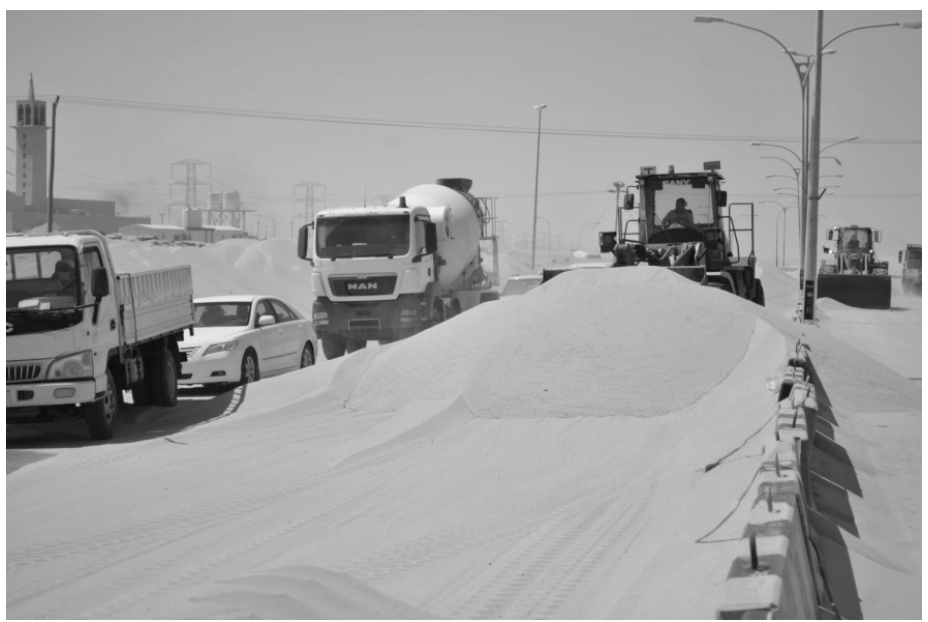

Figure 1(b). Partially closed lanes of AlWafra-Mena Abdallah Road (Author's camera, August 2018).

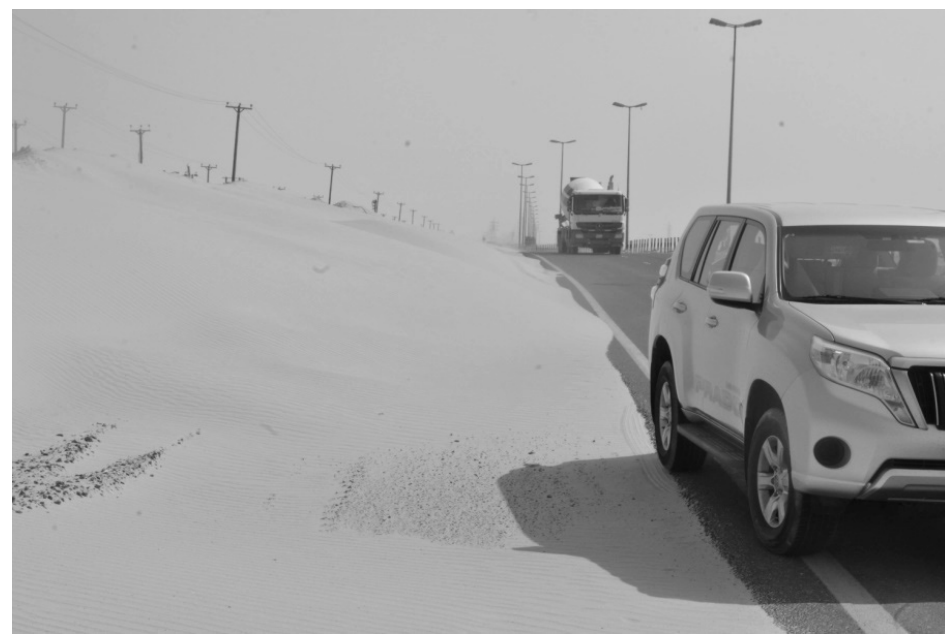

Figure 1(c). Sand encroaching on AlWafra-AlZoor Road (Author's camera, August 2018). 
This paper aims to investigate and develop long-term, sustainable solutions for the sand encroachment problem on roads in Kuwait. The study included site surveying of sand encroachment on affected roads to assess the nature and extent of the problem. Then, field sampling and testing of the accumulated sands were carried out. A preliminary concept design of a defensive system was developed and tested numerically in a virtual wind tunnel to produce an optimum, long-term, and sustainable solution.

\section{FACTORS AFFECTING SAND ENCROACHMENT IN KUWAIT}

The State of Kuwait, located at the tip of the Arabian Gulf, shares land borders with Iraq and Saudi Arabia. The latitude and longitude coordinates of the State of Kuwait are 29.378586 and 47.990341, respectively. AlHelal and AlAwadhi (2006), in their investigation of the effect of sand encroachment phenomena in Kuwait, identified seven triggering factors: (1) wind energy, (2) surface sediment, (3) vegetation density, (4) land use, (5) drainage density, (6) topographic change, and (7) vegetation type. Figure 2 shows a map of sand encroachment susceptibility in Kuwait produced by AlHelal and AlAwadhi (2006).

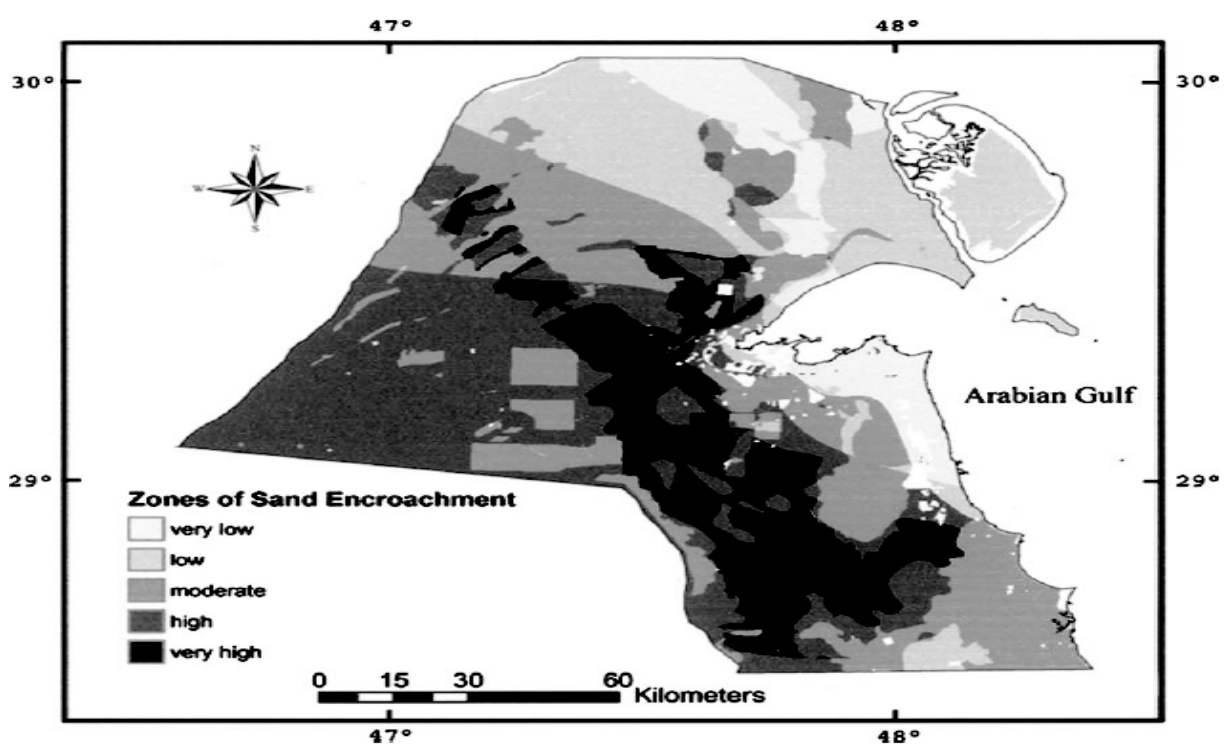

Figure 2. Map of sand encroachment susceptibility in Kuwait (AlHelal and AlAwadhi, 2005).

During the preliminary reconnaissance visits to the several reported affected sites, a spread of fine sand particles and the existence of unstable berms along the roads were observed (Figure 3a), which increased the risk of sand encroachment. When wind passes over the berms, it will carry a large amount of loose sand, which will be accumulated at the first fence it encounters. Additionally, random grazing in unauthorized grazing areas is considered a major cause of sand encroachment in Kuwait (Figure 3b). Green cover is negatively affected by grazing through the uprooting of plants, which dissociates the soil by breaking any crust, which ultimately leads to a decrease in resistance to wind erosion. Moreover, roadside barriers along the roads form undesirable artificial fences for the wind (Figure 3c). These types of fences have a high impact on decreasing the wind's speed crossing over the roads. The drop in the wind speed leads to early accumulation of the sand over the roads. This problem was partially solved in some portions of the roads by replacing the roadside barriers with vehicle crash barriers (Figure 3d), which have smaller diameters and therefore have less effect on the speed of the wind by applying the "aerodynamics method" concept. 


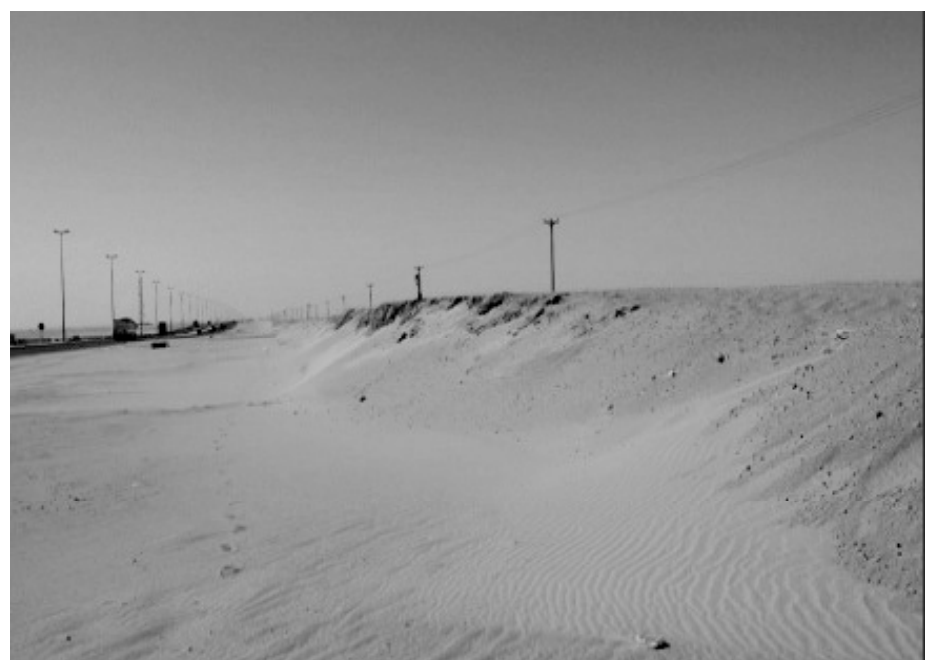

Figure 3(a). Berms along and near the road (Author's camera, Feb 2016).

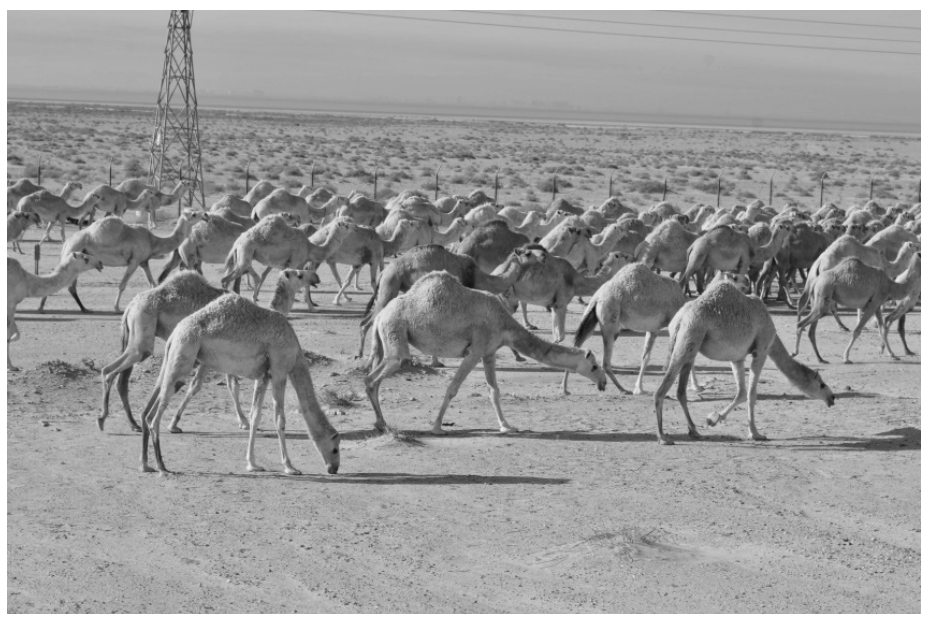

Figure 3(b). Random grazing in unauthorized grazing areas (Author's camera, May 2018).

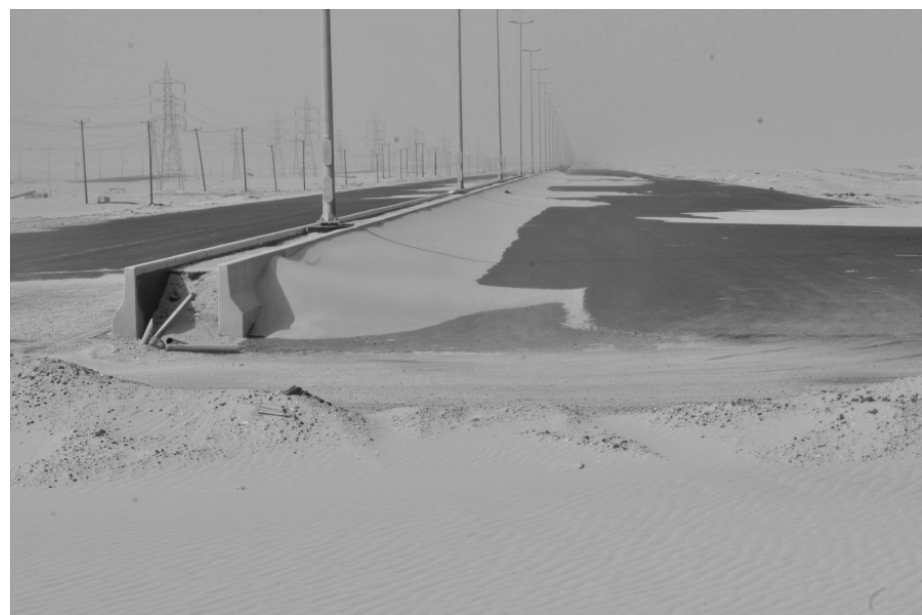

Figure 3(c). Roadside barriers (Author's camera, Aug 2018). 


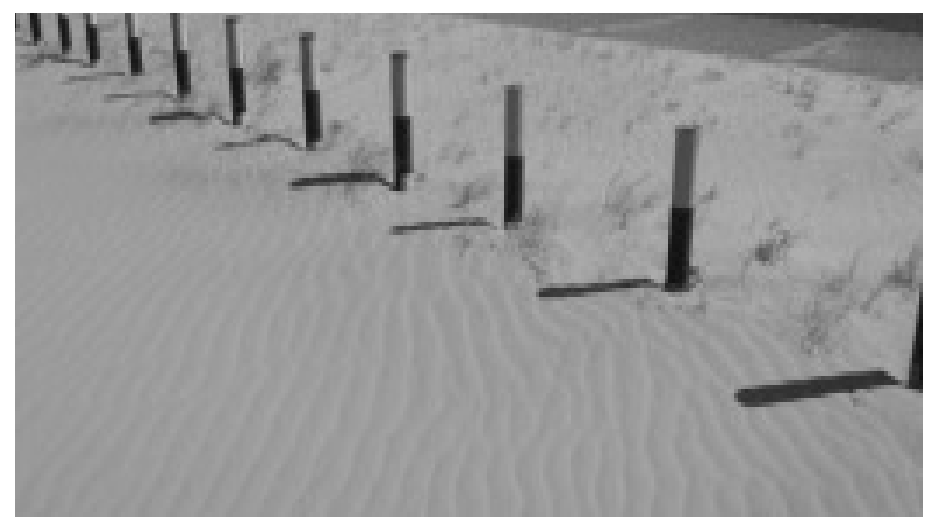

Figure 3(d). Vehicle crash barriers (Author's camera, Feb 2016).

\section{METHOD OF INVESTIGATION}

Mapping and surveys of the roads in Kuwait were carried out to assess the magnitude of the sand encroachment. The survey delineated major sand encroachment-threatened roads in Kuwait, which are AlSubia Road (Road \# 801), AlWafra-Mena Abdallah Road (AlWafra Road \# 306), and AlWafra-AlZoor Road (Om Sufag Road) (Figure 4). These roads constituted the study cases of the investigation. The coordinates and lengths of these roads are listed in Table 1. Surveys of the affected locations were carried out to assess the nature, magnitude, and degree of the sand encroachment hazard. Approximately $1 \mathrm{~m}$ of accumulated sand was measured on AlSubia Road, which led to permanent closure of part of the road.

To assess the accumulated sand characteristics in the study areas, sand samples were collected. It was important that the collected samples cover most of the study areas to ensure that the samples represent the whole area, resulting in realistic data and accurate assessment of the sand types (Figures 5 and 6). Large parts of AlSubia Road were unreachable due to total coverage by the accumulated sand; therefore, samples were taken from the first accessible portion of the road.

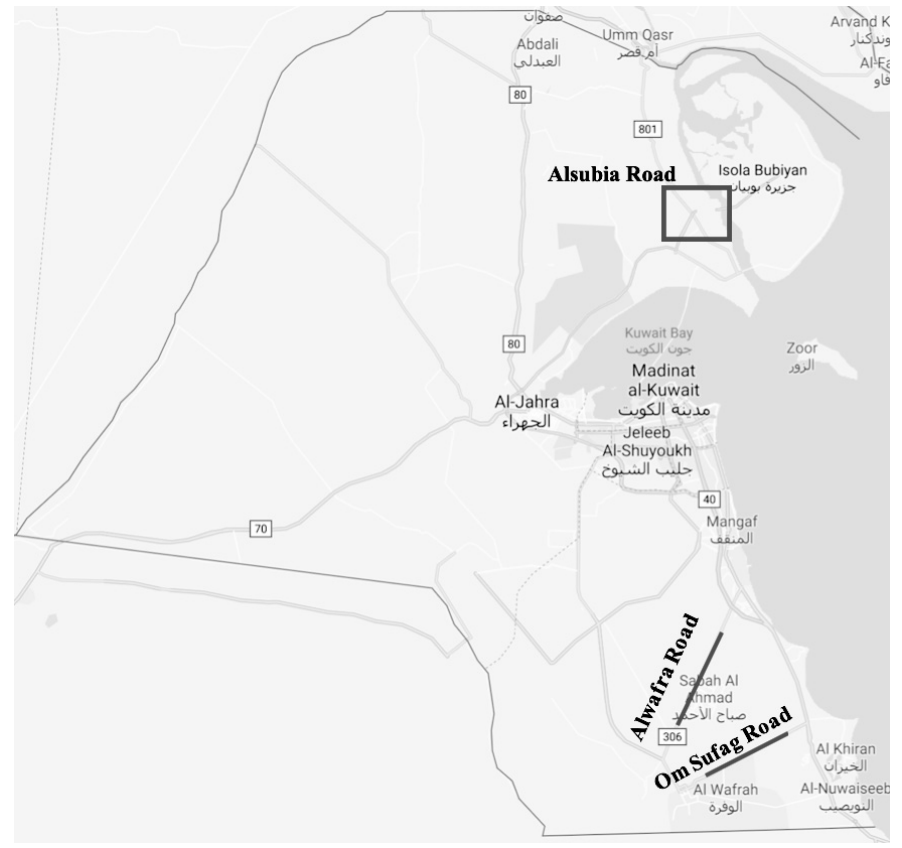

Figure 4. Roads included in the study. 
Table 1. Locations of roads included in the study.

\begin{tabular}{|c|c|c|c|}
\hline Road & $\begin{array}{l}\text { Coordinates: } \\
\text { Start point }\end{array}$ & $\begin{array}{l}\text { Coordinates: } \\
\text { End point }\end{array}$ & Length (km) \\
\hline $\begin{array}{l}\text { AlSubia Road } \\
\text { (Road. \# 801) }\end{array}$ & $\begin{array}{l}29^{\circ} 43^{\prime} 00.3^{\prime \prime} \mathrm{N} \\
48^{\circ} 02^{\prime} 59.5^{\prime \prime} \mathrm{E}\end{array}$ & $\begin{array}{l}29^{\circ} 43^{\prime} 10.2^{\prime \prime} \mathrm{N} \\
48^{\circ} 05^{\prime} 47.6^{\prime \prime} \mathrm{E}\end{array}$ & 4.5 \\
\hline $\begin{array}{l}\text { AlWafra-Mena Abdallah Road } \\
\text { (AlWafra Road. \#306) }\end{array}$ & $\begin{array}{l}28^{\circ} 51^{\prime} 21.8^{\prime \prime} \mathrm{N} \\
48^{\circ} 04^{\prime} 01.2^{\prime \prime} \mathrm{E}\end{array}$ & $\begin{array}{l}28^{\circ} 42^{\prime} 37.4^{\prime \prime} \mathrm{N} \\
47^{\circ} 59^{\prime} 21.5^{\prime \prime} \mathrm{E}\end{array}$ & 20 \\
\hline $\begin{array}{l}\text { AlWafra-AlZoor Road } \\
\text { (Om Sufag Road) }\end{array}$ & $\begin{array}{l}28^{\circ} 37^{\prime} 09.1^{\prime \prime} \mathrm{N} \\
48^{\circ} 01^{\prime} 02.2^{\prime \prime} \mathrm{E}\end{array}$ & $\begin{array}{l}28^{\circ} 43^{\prime} 11.0^{\prime \prime} \mathrm{N} \\
48^{\circ} 15^{\prime} 00.4^{\prime \prime} \mathrm{E}\end{array}$ & 29 \\
\hline
\end{tabular}

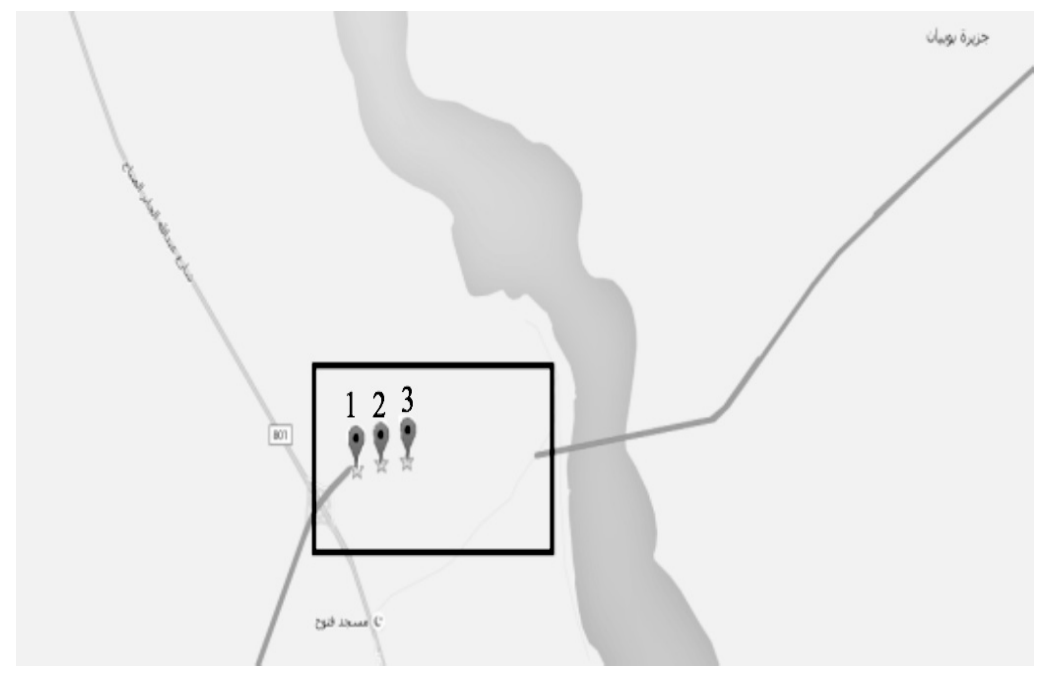

Figure 5. Sample locations and numbers at AlSubia Road.

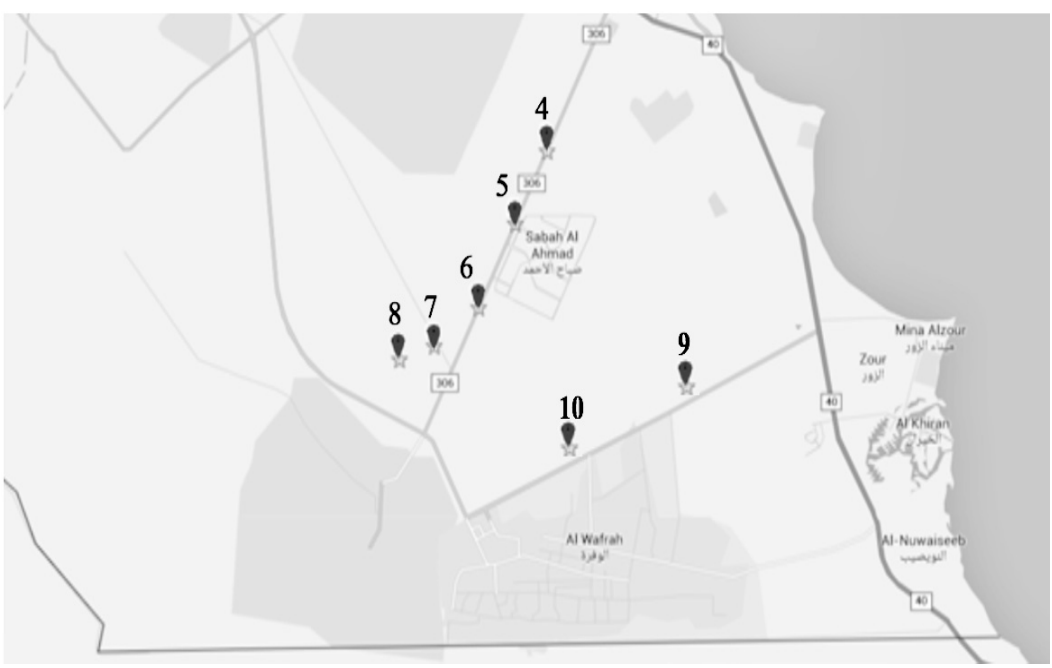

Figure 6. Sample locations and numbers at AlWafra-Mena Abdallah Road and AlWafra-AlZoor Road. 
The collected samples were tested in the laboratory for the fine percentage ( $\leq 2 \mathrm{~mm}$ in diameter), as Berte et al. (2010) found that fine particles with diameters less than $2 \mathrm{~mm}$ are the most suitable for sand encroachment. Table 2 lists the results of the sieving tests and the locations of the samples. The results of the fine fractions showed that approximately $94 \%$ of the collected sand samples have a diameter of $<2 \mathrm{~mm}$, which makes the sand profiles at the sites highly exposed to the encroachment risk. The fine fraction for sample no. 9 indicated a value of $63 \%$, which is lower than the average. However, Figure 6 shows that the location of sample \#9 was off the road and into the surrounding berm area.

Table 2. Percentages of fines in soil samples.

\begin{tabular}{|c|c|c|}
\hline Sample \# & \% Fines (<2 mm) & \multirow{2}{*}{ Location } \\
\hline 1 & 100 & \multirow{2}{*}{ AlSubia Road } \\
\hline 2 & 100 & \\
\hline 3 & 98.7 & \multirow{2}{*}{ AlWafra-Mena Abdallah Road } \\
\hline 4 & 99.48 & \\
\hline 5 & 96.52 & \\
\hline 6 & 99.04 & \\
\hline 7 & 89.96 & \multirow{2}{*}{ AlWafra-AlZoor Road } \\
\hline 9 & 93.53 & \\
\hline 10 & 98.98 & \\
\hline Average & 94.321 & \\
\hline
\end{tabular}

As reported by AlHelal and AlAwadi (2006), wind direction and speed are major factors affecting sand encroachment. Therefore, it was important to analytically assess those factors to produce a design for an effective protective system against sand encroachment. Data of daily wind records, every three hours, for the past 35 years (1979-2015) were collected. These results were processed, resulting in the "wind rose" (Figure 7), which is a graphical representation of the direction and speed of prevailing wind in the area. The wind rose for the State of Kuwait indicated that the northwest direction prevails with an average speed of 6-8 m/s. Figure 8 merges the alignment of the sand movement (Figure 2) and prevailing wind directions in Kuwait (Figure 7). Figure 8 shows that all areas included in this study are under direct threat of sand encroachment because they are located in the cross direction of sand corridors and perpendicular to the direction of the prevailing wind direction. 


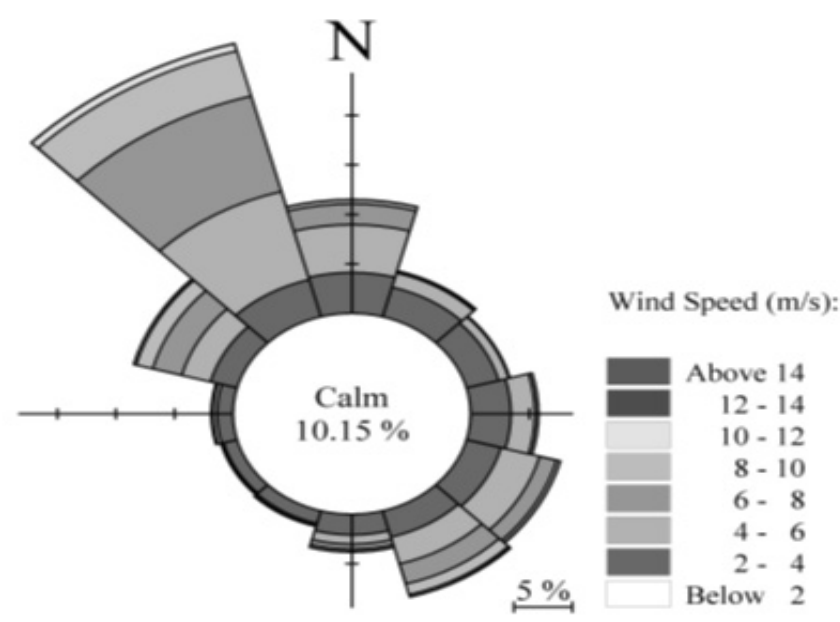

Figure 7. Wind rose showing the prevailing wind speed and direction in the State of Kuwait.

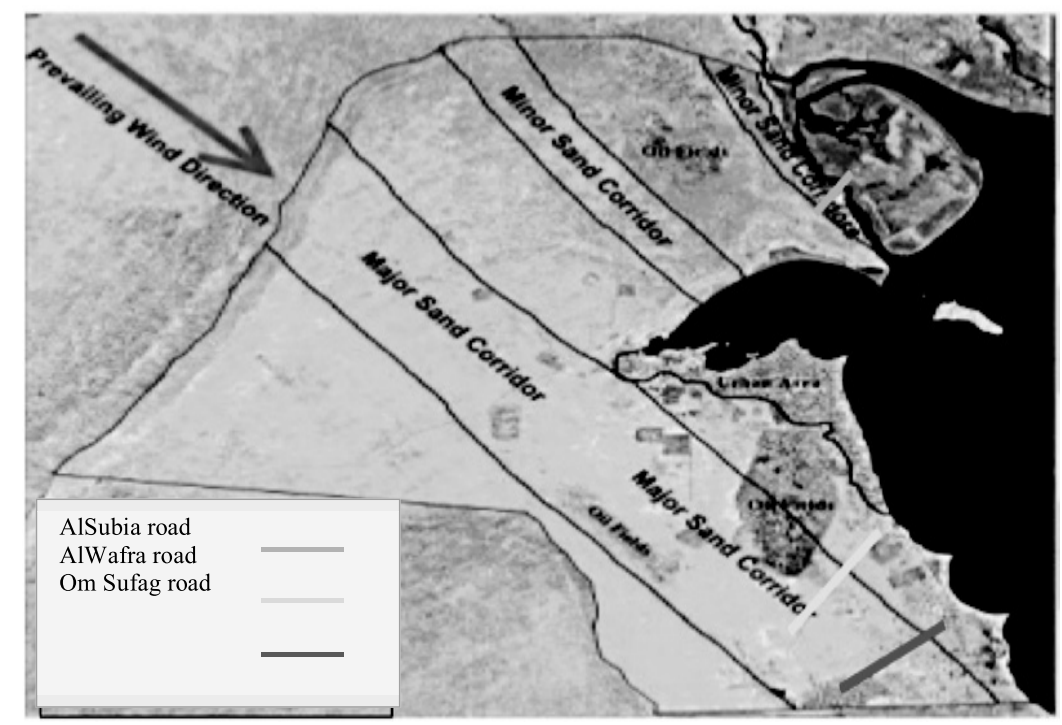

Figure 8. The main sand movement paths in Kuwait and prevailing wind direction. (eMISK, 2016).

\section{DEVELOPMENT OF THE DESIGN CONCEPTS}

The process of establishing preliminary design concepts is based on the analysis of collected sand samples from the study areas, wind speed, and direction, and previously applied solutions in similar arid areas. Preliminary investigations of the one-element solutions, which were applied in Mauritania (Berte et al., 2010) and China (Dong et al., 2002; Zhiwen et al., 2003), indicated that those solutions cannot be implemented in Kuwait for several reasons. In Mauritania, only short reed fences (type of plant) had been used, leading to a shortening of the system's lifecycle because fences will be buried with accumulated sand. Berte et al. (2010) reported that Mauritania's system requires continuous monitoring with short intervals. In China, the system depends mainly on planting tree belts along the roads or any sheltered area. Depending only on the use of tree belts is not feasible in Kuwait since such systems will need easy and continuous access to water tables, which are not available in Kuwait near the threatened roads, and providing a large pumping station to supply the system with water will make the solution economically unfeasible. 
Wilson (1986) found that no single type of windbreak provides the best protection in all circumstances and by all performance criteria. Therefore, it was concluded that a single defensive system is not the best solution, and hence, attention was directed to the use of a composite protective system.

Dong et al. (2002) reported that, for a protective system to be effective, it needs to use several control procedures with the mechanisms of (1) reducing or eliminating sand supply, (2) preventing dunes from mobilization by interfering between the airflow and the sand surface, (3) diverting drifting sand from the protected targets, (4) enhancing sand transport capacity so that no settlement takes place nearby the protected area, and (5) reducing the ability of the wind to erode the sand. Dong et al. (2002) further added that the specific control measures to be adopted are dependent on the local environment, materials availability, required life of the shelter system, and economic feasibility. Therefore, from the solutions applied in Mauritania and China, it is apparent that fences and vegetation can be considered valid options in a composite design for the case in Kuwait, rather than being the main system themselves.

In the process of developing the concept design, the percentage of fines, wind speed and direction, porosity of fences, and aerodynamics were considered. Analysis of the collected sand samples and wind data indicated that fines make up to $94 \%$ of the sand in the studied areas, a northwest wind with a speed of $6-8 \mathrm{~m} / \mathrm{s}$ prevails in Kuwait, and the prevailing wind direction is perpendicular to the studied roads. Moreover, wind is in the direction of sand movement (Figure 8). Berte et al. (2010) found that fences should be fixed at a $90^{\circ}$ orientation with the prevailing wind direction to obtain optimal reduction of wind speed without causing a wind turbulence. Therefore, the protective system needs to be parallel to the road and therefore perpendicular to the prevailing wind.

The concept design of the composite protective system is based on several elements, including fences, green belt, and gravel-stabilized areas. Fences are parallel to the roads with specific porosity ratios, spacing, and heights that can decrease the wind speed, resulting in early accumulation of sand and decrease in the risks of sand encroachment in protected regions. In addition, lines of trees spread in rows are one of the major elements of the composite system. The lines of trees are to be placed between the fences, parallel to the road, and in a zigzag pattern to eliminate the gaps between the trees and hence assist in decreasing the wind speed and overcoming the regeneration of the wind's speed between fences (Figure 9). In addition, an aerodynamics method was proposed by removing obstacles from the path of the wind to avoid sand accumulation over the roads.

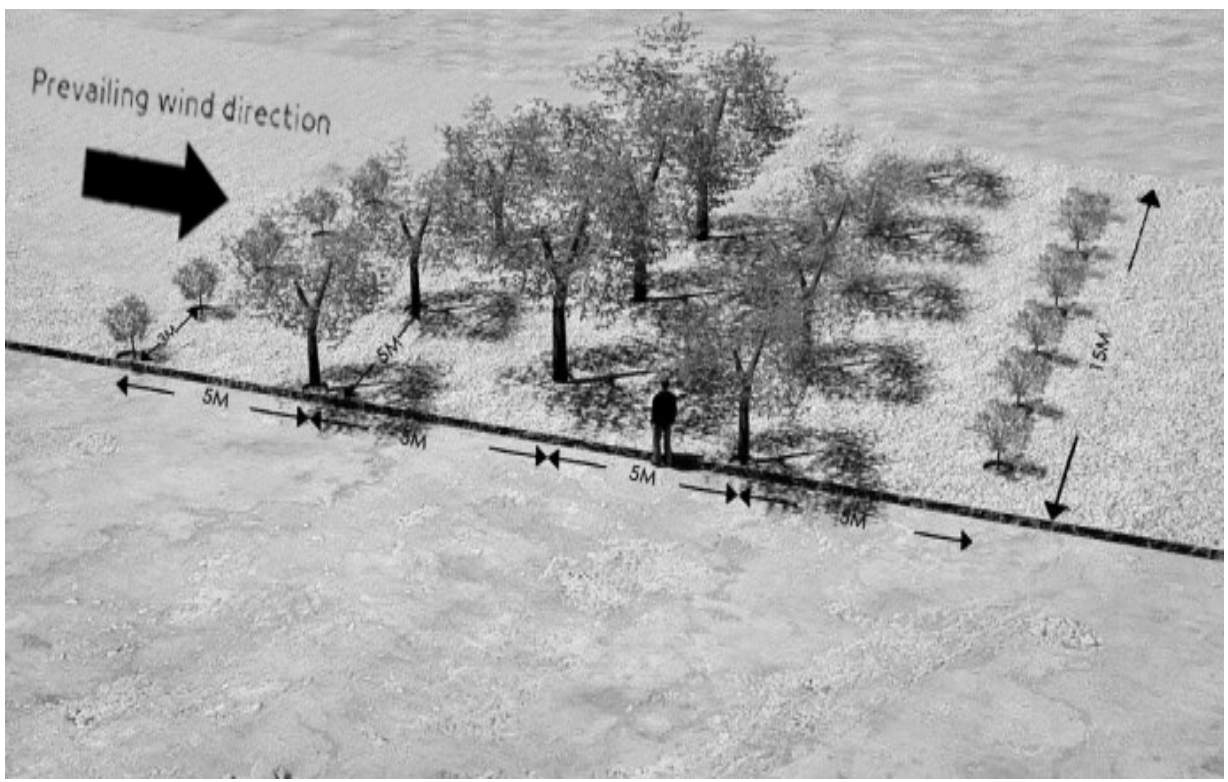

Figure 9. Tree row design (Zigzag pattern). 
Simulation models reported by the Ministry of Agriculture in British Columbia (2015) indicated that turbulence and accumulation span are inversely proportional to porosity (Figure 10). Therefore, the goal is to find the most suitable porosity that gives a required drop in wind speed causing early deposition of the sand and at the same time does not cause wind turbulence. The report issued by the Ministry of Agriculture in British Columbia (2015) found that effective systems should achieve at least a $75 \%$ reduction in wind speed.

The proposed concept design included two rows of fences ( $2 \mathrm{~m}$ high and $5 \mathrm{~km}$ long each) separated by $80 \mathrm{~m}$. The porosity ratios of the fences were chosen to vary at $0 \%, 10 \%, 20 \%, 30 \%, 40 \%$, and $50 \%$ with an average wind speed of $6-8 \mathrm{~m} / \mathrm{s}$, which was determined from the collected data and wind rose (Figure 7). Additionally, the concept design included five rows of trees with heights of $1 \mathrm{~m}, 3 \mathrm{~m}$, and $5 \mathrm{~m}$, and the rows are $5 \mathrm{~m}$ apart. Heisler and Dewalle (1988) found that the height of the windbreak (fences or trees) affects the efficiency of the break to reduce the wind speed and therefore affects its ability to deposit the sand. Figure 11 shows a sketch of the concept design with all the elements of the composite system.

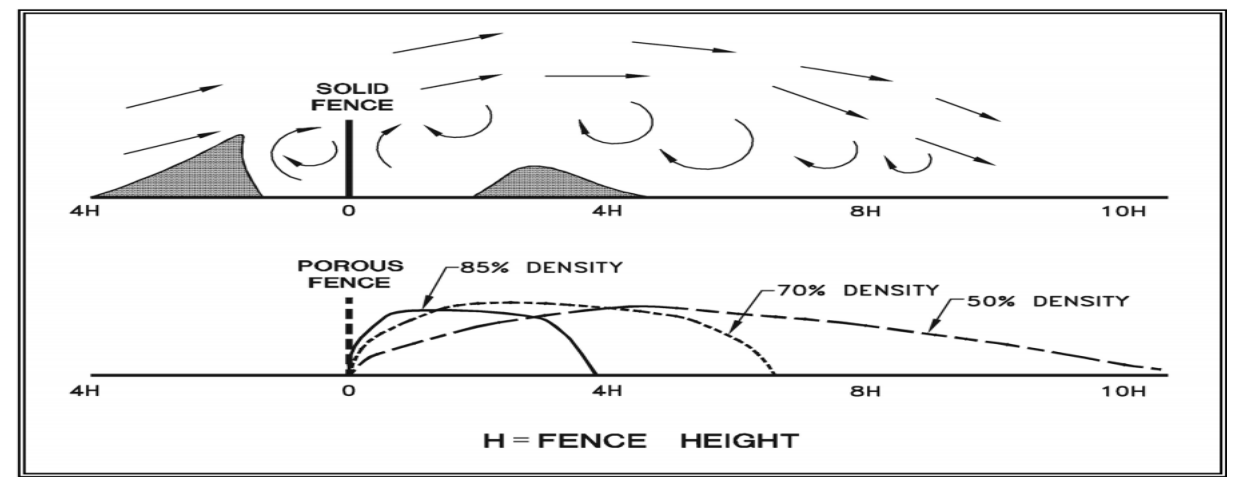

Figure 10. Turbulence and accumulation range vs. fence porosity (Ministry of Agriculture of British Columbia, 2015).

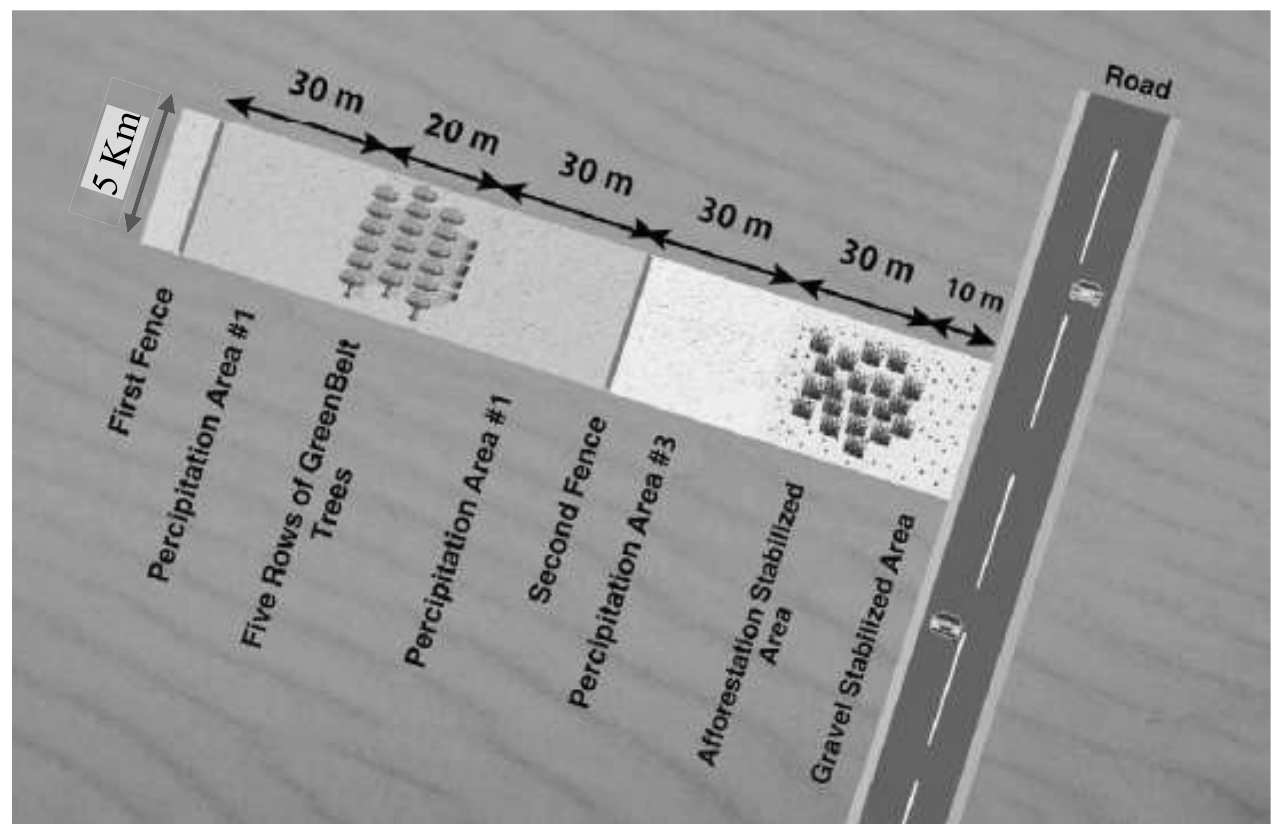

Figure 11. Concept design of the composite system showing all elements. 


\section{TESTING OF THE DESIGN CONCPETS}

Validation of the design of aerodynamic objects is typically performed by wind tunnel experiments. However, because full-scale wind tunnel experiments are very expensive and time-consuming, numerical modeling of the wind tunnel is usually adopted for the testing and validation of design concepts. Such numerical wind tunnel modeling has been used in several applications, such as modeling wind load for structural analysis (Kerklaan, 2006), wind visualization techniques for architects (Castro, 2015), and assessing aerodynamics in cycling (Wolbert, 2017).

Virtual wind tunnel simulations were used to investigate the validity of the proposed concept protective system in this study. Virtual wind tunnel simulation provides visual image representation of the variations in wind speed and the formation of turbulence (if any) through the system and assists in determining the optimum porosity of the fences. The target was to decrease wind speed before it arrived at the roads, resulting in early deposition of the sand over the roads. Moreover, decreasing wind turbulence between the fences will prevent erosion that causes dissociation of the sand layer, which makes it easily transported by the coming wind.

Wind flow simulations were made around fence models with different porosities and afforestation systems in the virtual wind tunnel constructed using a computational fluid dynamic (CFD) program (Autodesk Flow Design, 2014) to investigate the relationships between porosity, sand accumulation, and turbulence. The software provides a three-dimensional demonstration, accompanied by a visual presentation of airflow. The virtual wind tunnel is simply created by dragging its sides to the desired dimensions. Thereafter, the software automatically develops an analysis grid based on imported 3D model and wind tunnel characteristics. Furthermore, the wind speed and direction inside the virtual wind tunnel can be controlled. Moreover, the software reported results in both numerical and graphical presentations, describing the changes to the wind speed or/and direction.

\section{RESULTS AND ANALYSIS}

The major requirement of the Ministry of Agriculture in British Columbia (2015) for an effective fence as part of a sand encroachment protective system is minimizing the wind turbulence, achieving a $75 \%$ reduction in wind speed and allowing sand to pass through the fences and be accumulated at a minimum distance from the fences of 10 times the height of the fences. The minimum distance for sand accumulation is a requirement to avoid accumulation of sand over fences for the purpose of extending their lifetime.

For this study, applying a test wind speed of $10 \mathrm{~m} / \mathrm{s}$ and using 2-meter-high fences, these requirements translate to a wind speed of $2.5 \mathrm{~m} / \mathrm{s}$, and sand is accumulated at a minimum distance of 20 meters from the fences.

The results of the wind tunnel simulations with the selected fence porosities are shown in Figure 12 (a, b. c. d, e, and f) and listed in Table 3. The results indicate that recorded turbulence was high in $0 \%, 10 \%$, and $20 \%$ porosity fences, while limited turbulence was recorded in $30 \%$ porosity fences. However, only fences with $40 \%$ and $50 \%$ porosities recorded no turbulence. Among the porosities with no turbulences, only 50\% porosities yielded no accumulation of sand over the fences and the accumulation area at $20 \mathrm{~m}$ from the fence. Additionally, the wind speed recorded was less than $3 \mathrm{~m} / \mathrm{s}$, which was close to a $75 \%$ reduction of the maximum test speed of $10 \mathrm{~m} / \mathrm{s}$. 


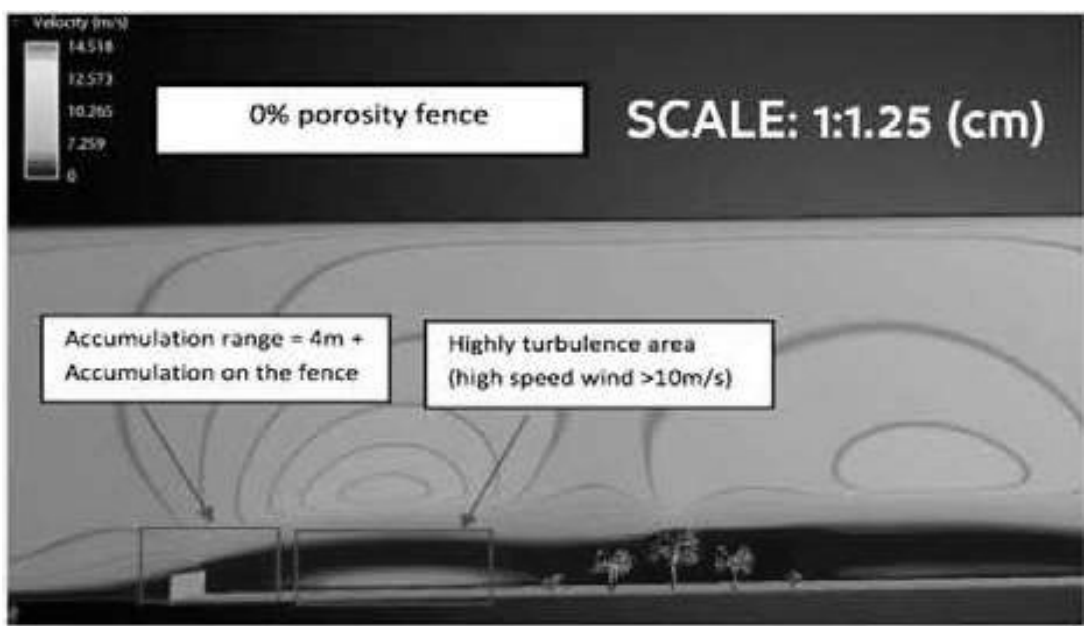

Figure 12(a). Fence with $0 \%$ porosity.

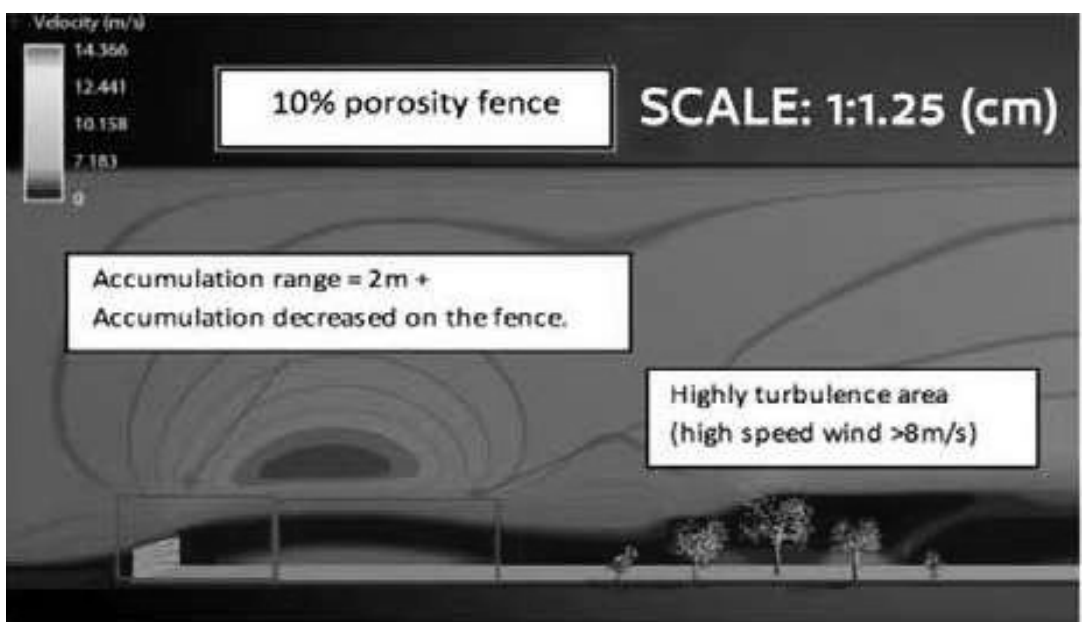

Figure 12(b). Fence with 10\% porosity.

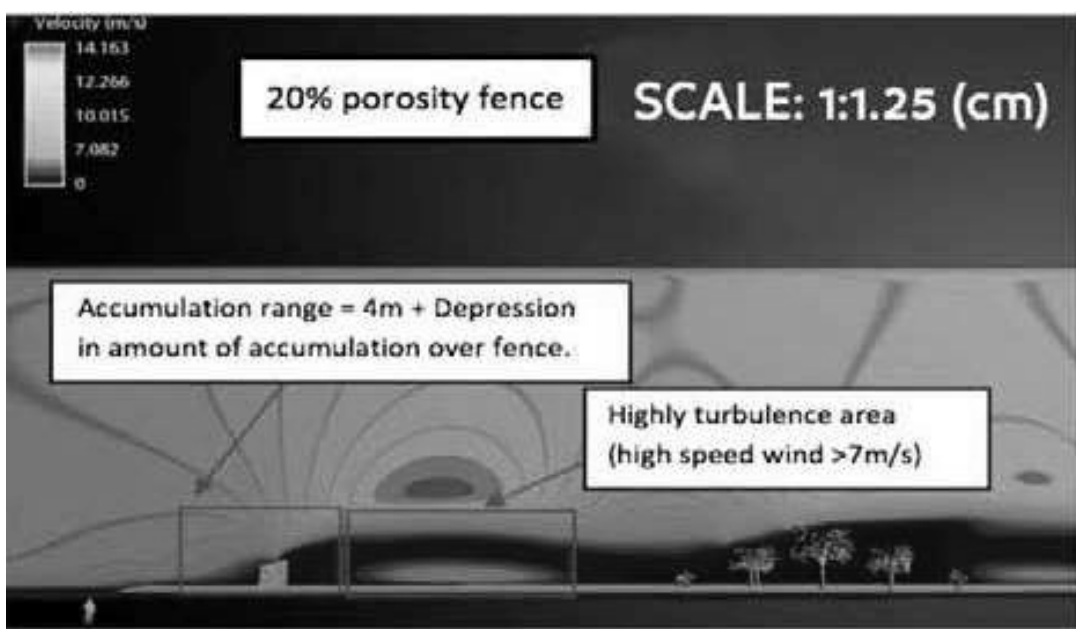

Figure 12(c). Fence with $20 \%$ porosity. 


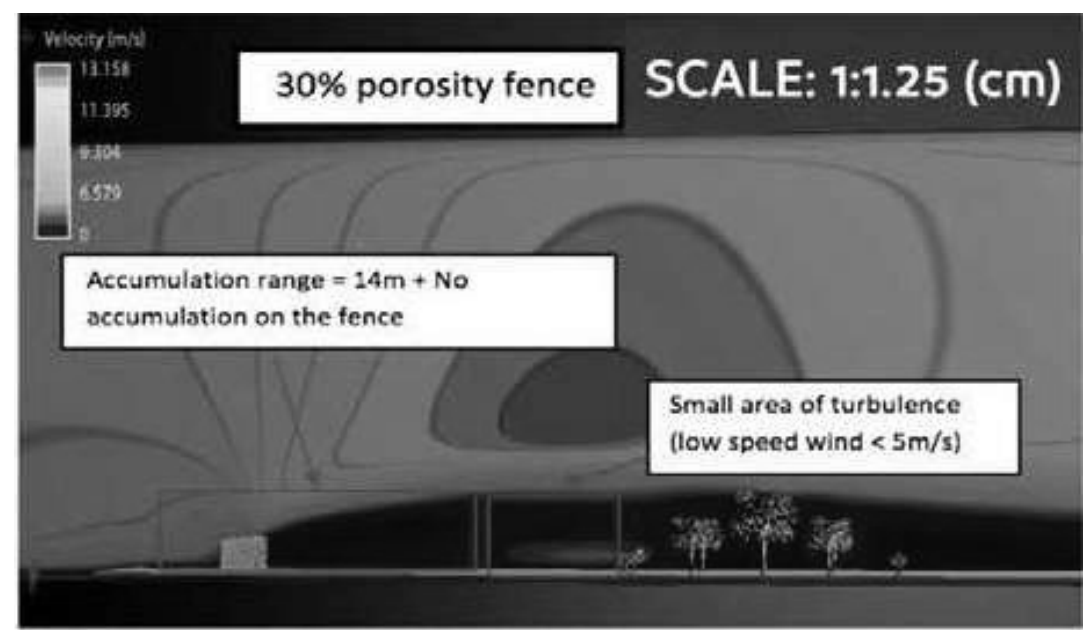

Figure 12(d). Fence with 30\% porosity.

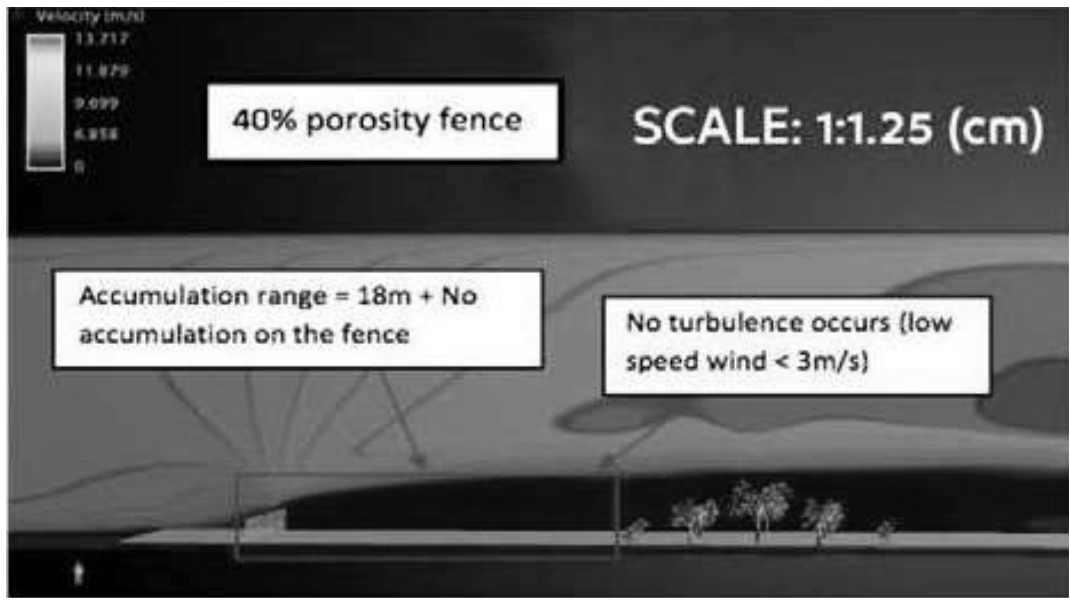

Figure 12(e). Fence with $40 \%$ porosity.

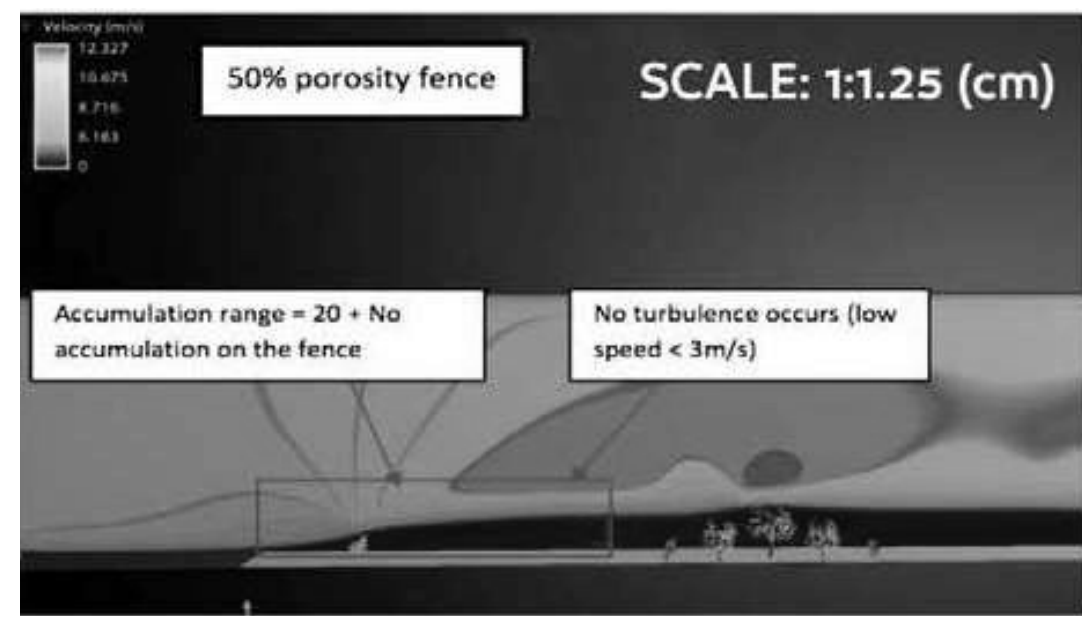

Figure 12(f). Fence with 50\% porosity.

Figure 12. Fence porosity vs. distance of sand accumulation and turbulence. 
Table 3. Wind tunnel simulation results.

\begin{tabular}{|c|c|c|}
\hline Porosity & Accumulation area & Turbulence \\
\hline $0 \%$ & $\begin{array}{c}\text { "Over fence" and accumulation area extends } \\
\text { to } 4 \mathrm{~m} \text { from fence }\end{array}$ & $\begin{array}{l}\text { High turbulence area with high wind } \\
\text { speed }(>10 \mathrm{~m} / \mathrm{s})\end{array}$ \\
\hline $10 \%$ & $\begin{array}{l}\text { "Over fence" and accumulation area extends } \\
\text { to } 2 \mathrm{~m} \text { from fence }\end{array}$ & $\begin{array}{l}\text { High turbulence area with high wind } \\
\text { speed }(>8 \mathrm{~m} / \mathrm{s})\end{array}$ \\
\hline $20 \%$ & $\begin{array}{l}\text { "lower over fence accumulation" and } \\
\text { accumulation area extends to } 4 \mathrm{~m} \text { from fence }\end{array}$ & $\begin{array}{l}\text { High turbulence area with high wind } \\
\text { speed }(>7-8 \mathrm{~m} / \mathrm{s})\end{array}$ \\
\hline $30 \%$ & $\begin{array}{l}\text { No accumulation over fences and } \\
\text { accumulation area extends to } 14 \mathrm{~m} \text { from fence }\end{array}$ & $\begin{array}{l}\text { small turbulence area with low wind } \\
\text { speed }(<5 \mathrm{~m} / \mathrm{s})\end{array}$ \\
\hline $40 \%$ & $\begin{array}{l}\text { No accumulation over fences and } \\
\text { accumulation area extends to } 18 \mathrm{~m} \text { from fence }\end{array}$ & No turbulence occurs \\
\hline $50 \%$ & $\begin{array}{l}\text { No accumulation over fences and } \\
\text { accumulation area extends to } 20 \mathrm{~m} \text { from fence }\end{array}$ & No turbulence occurs \\
\hline
\end{tabular}

The effects of aerodynamic elements of the model were assessed by testing the effects of removing barriers, such as trees near the streets, roadside barriers, and electrical boxes, from the direction of the wind on mitigation of the sand encroachment risks. The main aim of the aerodynamics concept in the design is maintaining the wind speed over the roads to avoid sand deposition. Figures 13 ( $a$ and $b$ ) show a comparison of the results for the effects of barriers along the streets on reduction in wind speed. Figure 13 (a), which is for a model with road barriers, shows that the wind lost approximately half of its speed due to road barriers. In addition, turbulence is notable at the right side of the tested road due to the road barriers. In contrast, Figure 13 (b), which is for a model without road barriers, shows that the wind maintained its speed and that the wind turbulence was completely eliminated.

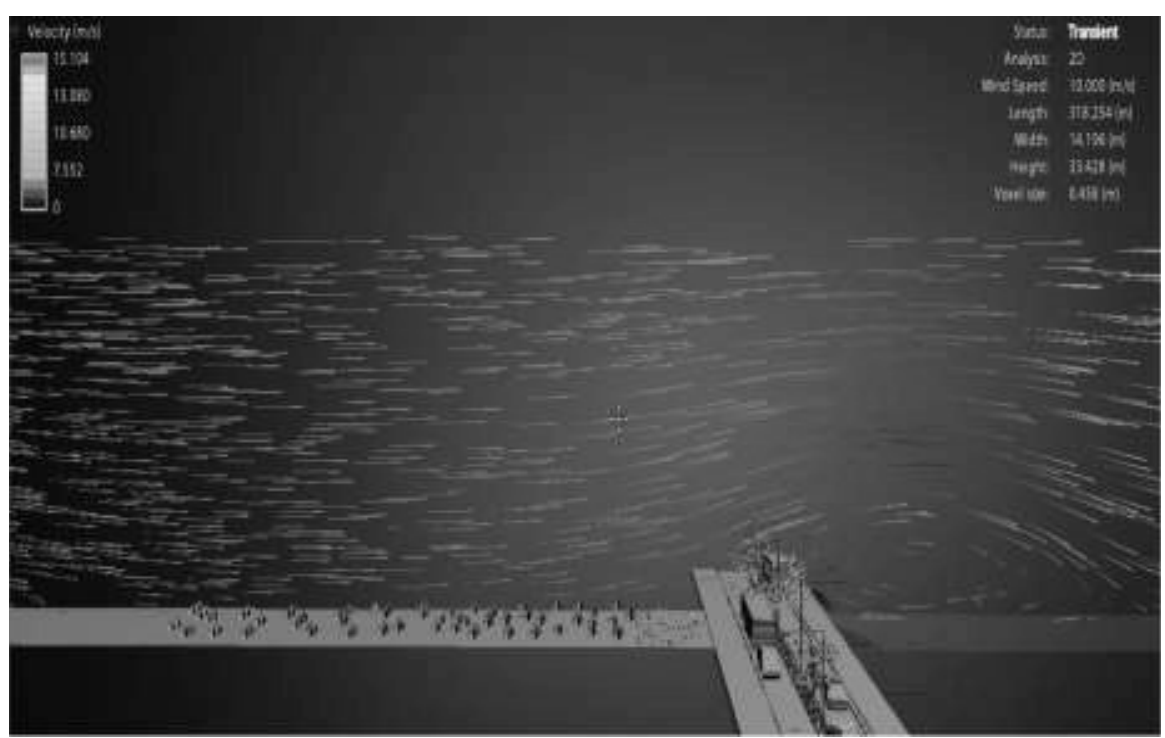

Figure 13(a). Wind speed variation and turbulence with barriers. 


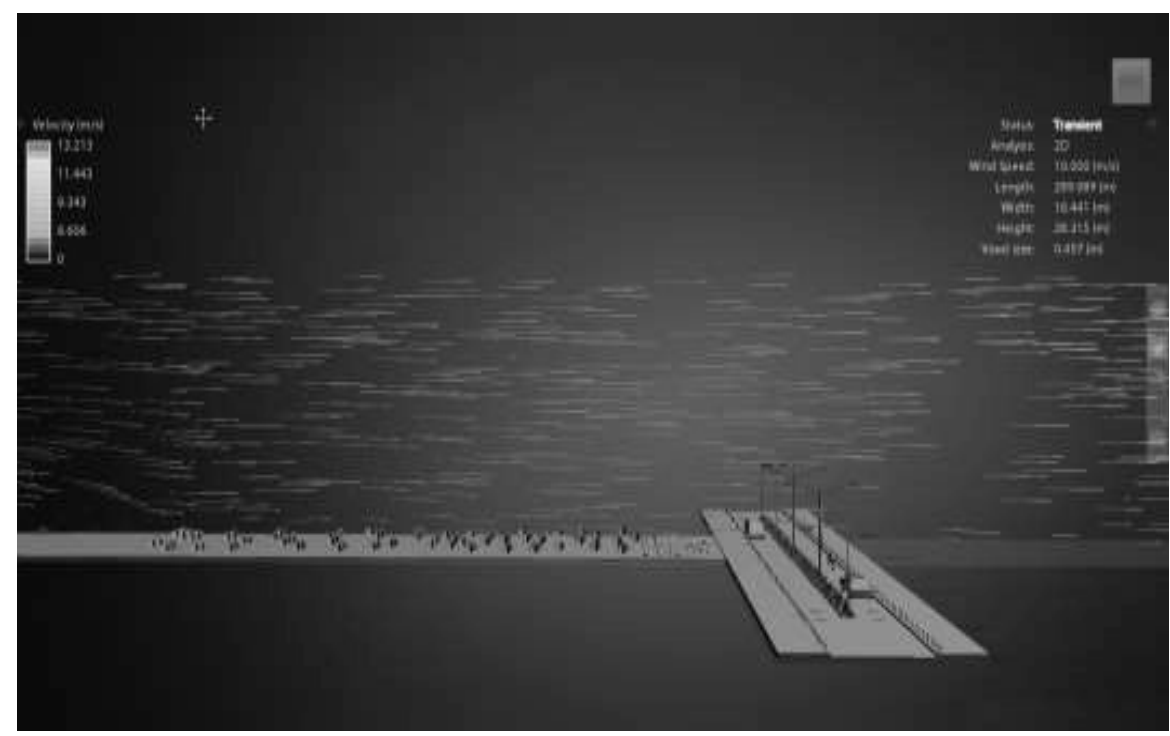

Figure 13(b). Wind speed variation and turbulence without barriers.

Afforestation was used in the model due to its several benefits such as reducing wind speed between the first fence and first trees row, preserving moisture in the soil, which can positively stabilize the surface soils, and also provides valuable environmental impact due to the absorption of the high quantity of $\mathrm{CO}_{2}$ emitted from vehicles on the test road sections.

The final design was also optimized by considering the area between the defensive system and the roads, where the wind recovers part of its speed. Stabilizing this area by using, for example, shrubs, helps maintain the soil moisture and form a crust, which creates a protective layer against erosion. Gravels are also used as stabilizing agents to decrease the rate of evaporation from the soil layer. Therefore, soil layers maintain their cohesion, resulting in more resistance to wind erosion and sand drifting.

\section{CONCLUSIONS}

The study was initiated with the objective of investigating and developing long-term, sustainable solutions for the sand encroachment problem on roads in the State of Kuwait. Analysis of the wind data indicated that the prevailing wind in Kuwait is from the northwest direction at an average speed of $6-8 \mathrm{~m} / \mathrm{s}$, which is perpendicular to the study's roads. In addition, testing of the collected sand samples from the sites indicated that the sand distribution profile consists of approximately $94 \%$ fines (particle diameter $<2 \mathrm{~mm}$ ), which is highly vulnerable to sand encroachment.

Investigating developed protective systems and analyzing particular factors at the sites indicated that a composite system of biological and mechanical elements should be adopted to form an optimum and sustainable protective system. The proposed preliminary concept composite system included 2-meter-high double porous fences and five rows of drought-resistant trees as the major elements of the design system. Testing of the preliminary concept design in a virtual wind tunnel indicated that using $50 \%$ porosity led to the optimum wind reduction $(\approx 75 \%)$, no turbulence area, and maximum sheltered area without sand accumulation over the fences. The results of this study have the potential to improve and effectively enhance the solutions of sand encroachment on roads in the State of Kuwait, where new urban communities are being developed, especially those located in areas vulnerable to sand encroachment. 


\section{REFERENCES}

AlHelal, A. and AlAwadhi, J. 2006. Assessment of sand encroachment in Kuwait using GIS. Environmental Geology, 49: 960-967.

Al Hemoud, A., Al Dousari, A. and Misak, R., Al-Sudairawi, M., Naseeb, A., Al-Dashti, H., and Al-Dousari, N. 12019. Economic Impact and Risk Assessment of Sand and Dust Storms (SDS) on the Oil and Gas Industry in Kuwait. Sustainability, 01/2020, 11(200) 1-19.

Al-Awadhi, J. and Misak, R. 2000. Field assessment of aeolian sand processes and sand control measures in Kuwait. Kuwait J Sci Eng, 27(1): 156-176.

Autodesk Flow Design, 2014. Flow Design Preliminary Validation Brief. . http://www.simhub.autodesk.com/resources/flowdesign-wind-tunnel-validation-brief.

Ayala, I. and Goudie, A. 2010. 'Geomorphological Hazards and Disaster Prevention' Cambridge University Press.

Berte, C., Mohamed, C. and Saleck, S. 2010. Fighting sand encroachment Lessons from Mauritania. Fao Forestry Paper.

Boulghobra, N., Saifi, M. and Fattoum, L. 2015. Sand encroachment in the Saharan Algeria; the not declared disaster - Case study: In-Salah region in the Tidikelt. GRF Davos Planet@Risk 3(1).

Castro, R.A.M. 2015. Wind analysis in the early design stage: An empirical study of wind visualization techniques for architects. Ph. D. thesis. School of Architecture and Design, College of Design and Social Context. RMIT University.

Cook, N.J. 1982. Towards better estimation of extreme winds. Journal of Wind Engineering and Industrial Aerodynamics, 9(3), pp. 295-323.

eMISK, 2016. Environmental Monitoring Information System of Kuwait. http://www.emisk.org.

Dong, Z., Chen, G., He, X., Han, Z., and Wang, X. 2002. Controlling blown sand along the highway crossing the Taklimakan Desert. Journal of Arid Environments 57, 2004, pp. 329-344.

Heisler, G.M., Dewalle, D.R. 1988. Effects of windbreak structure on wind flow. Agriculture, Ecosystems \& Environment. (2223), August 1988, Pages 41-69.

Hidore, J. and Albokhair, Y. 1982. Sand Encroachment in Al-Hasa Oasis, Saudi Arabia. Geographical Review, 72(3), July 1982, pp. 350-356.

Katyal, J. and Vlek, P. 2000. 'Desertification: Concept, causes and amelioration. ZEF Discussion Papers on Development Policy (33).

Katyal, J.C. and Vlek, P.L.G. 2000. Desertification — Concept, Causes and Amelioration. ZEF Discussion Papers on Development Policy 33, Center for Development Research, Bonn.

Kerklaan, R.A.G. 2006. Design Tools for the Virtual Wind Tunnel, Setting up the geometry for CFD calculations. M. Sc. Thesis. Delft University of Technology.

Kerr, R.C. and Nigra, J.O. 1952. Eolian sand control. Bulletin of the American Association of Petroleum Geologists, 36(8), August 1952, pp. 1541-1573.

Ministry of Agriculture in British Columbia 2015. Wind and Snow Fences. Province of British Columbia.

Pye, K., Tsoar, H. 1990. Aeolian sand and sand dunes. Springer Science \& Business Media.

Wilson, J.D. 1986. On the choice of a windbreak porosity profile. Boundary-Layer Meteorology 38(1-2), January 1986, pp.37-49.

Wolbert, F.A.J. 2017. Development and validation of a low- cost system for assessing aerodynamics in cycling using computational fluid dynamics. Development of a low-cost 3D scan system with CFD for assessing aerodynamics in cycling. June 2017

Zhiwen, H., Tao, W., Qingwei, S., Zhibao, D., and Xunming, W. 2003. 'Sand harm in Taklimakan Desert highway and sand control. Journal of Geographical Sciences, 13(1), January 2003, pp.45-53. 